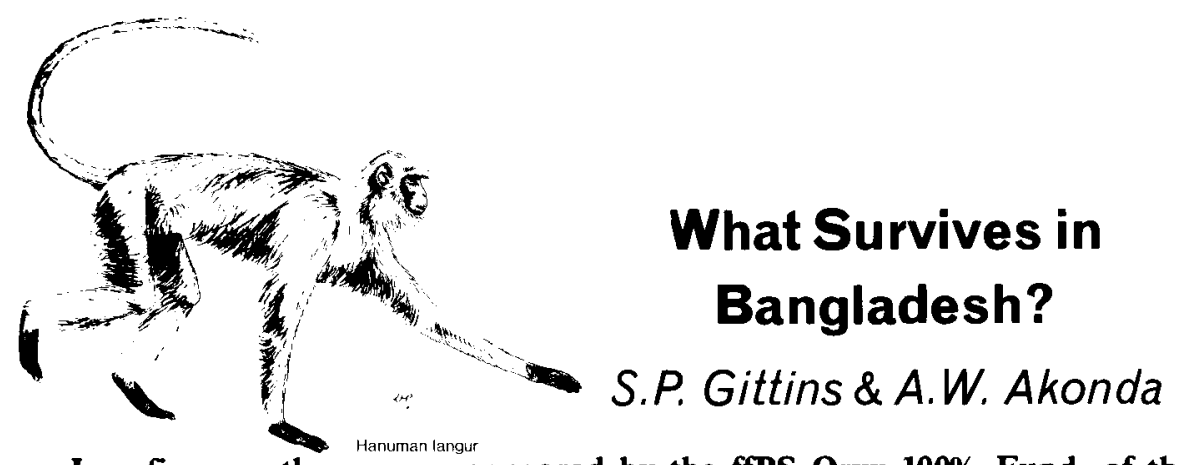

In a five-month survey, sponsored by the ffPS Oryx $100 \%$ Fund, of the distribution and numbers of primates in Bangladesh early in 1980, the authors visited most of the surviving natural forest. Their report shows that wildlife reserves are inadequate, both in quantity and quality, but acknowledges the Government's efforts in the face of great difficulties.

Bangladesh consists of a wide alluvial delta formed by the mouths of the Ganges, Jamuna, and Meghna Rivers, with some higher land in Sylhet and the south-east. The natural vegetation of the fertile alluvial plain has been largely cleared for cultivation, and the remaining natural forest is mostly on the deltaic swamps of the Sunderbans and in the hilly regions of Sylhet, Chittagong and

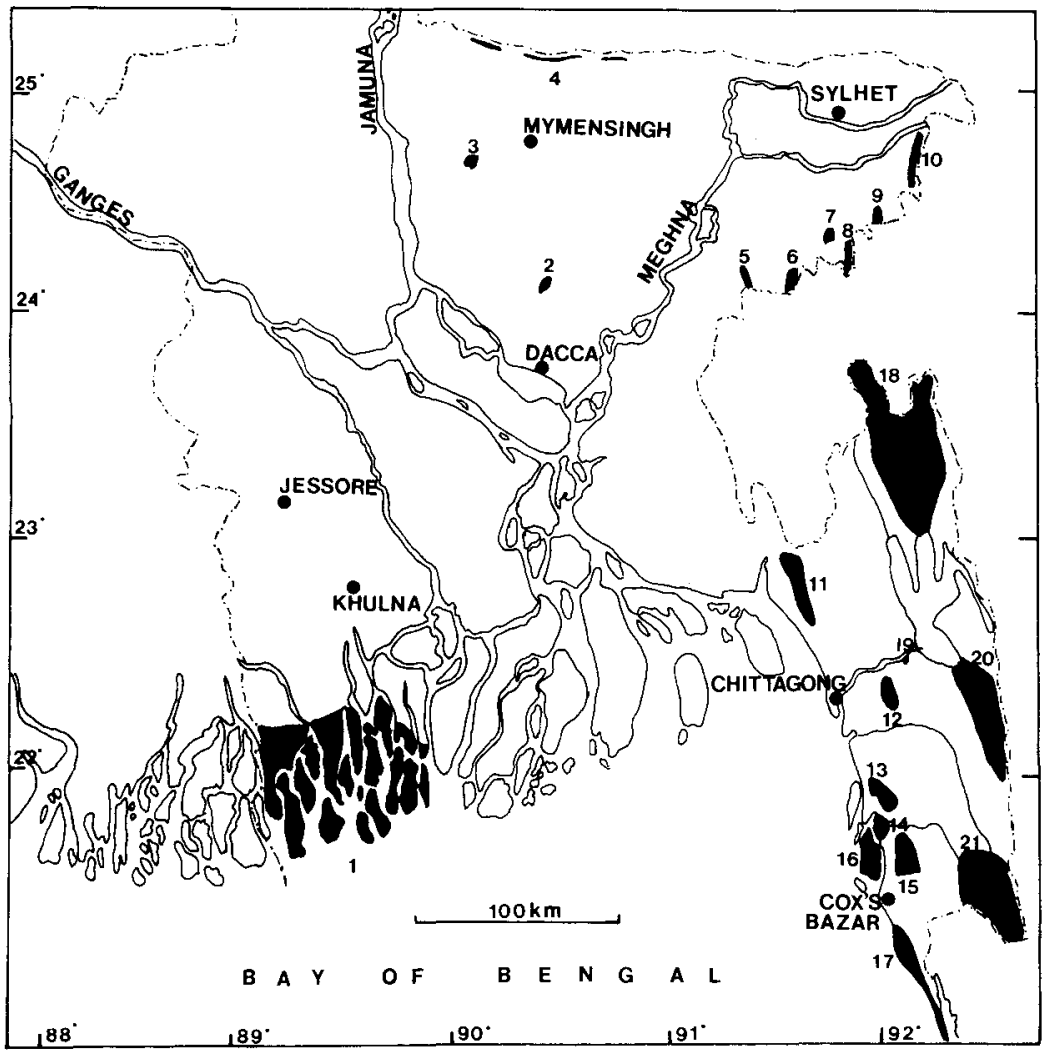

Main forest areas. The numbers refer to names listed in Table 1 overleaf. Boundaries are approximate. 
Type and Locality

Mangrove Forest

1. Sunderbans

14. Chokoria Sunderbans

Total

Deciduous Forest

2. Bhawal National Park

3. Madhupur Tract

(National Park)

4. Northern Mymensingh Other

Total
Natural Forest sq km

2274

0

2274

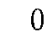

114

73

0

187
Scrub Forest

$\mathrm{sq} \mathrm{km}$

1487

46

1533
Total Area

sq km*

4025

84

4109

100

724

146

15

985
Semi-Deciduous/Evergreen Forests of Sylhet

5. Raghunandan

6. Tarap

7. West Bhanugach

8. Rajkandi

9. Harargaj

17

34

9

61

10. Patharia

28

Other

42

0

Total

191

100

270

15

458

58

61

27

81

86

54

554

921

589

Semi-Deciduous/Evergreen Forests of the South-East

11. Chittagong Northern

12. Chittagong Eastern

13. Chittagong Southern

15. Cox's Bazar Northern

16. Mohashkhali Island

17. Teknaf Peninsula

18. Chittagong Hill Tracts Northern

19. Sitapahar/Rampahar

20. Chittagong Hill Tracts Eastern

21. Sangu/Matamuhari Other

166

102

77

126

0

239

633

15

326

334

112

Total

2130

4782

Grand Total

* Includes forest plantation and cultivation.

the Chittagong Hill Tracts. There are three distinct types: mangrove; tropical deciduous (sal) and tropical semi-deciduous/evergreen. Much natural forest has been converted into forest plantation or degraded into scrub forest, bamboo and savanna, blocks of which now surround areas of natural forest and supply important habitats for some species - see Table 1 .

\section{Primate Distribution and Numbers}

We visited all the remaining natural forest blocks except those in the Chittagong Hill Tracts. Primate densities were estimated from transect walks, in which the density of groups in an area is calculated from the number of groups encountered divided by the transect area (i.e. the length of the transect multiplied by its estimated width). The number of primates is then calculated from the density of groups of each species multiplied by the average group size for each species, multiplied by the area of the forest block. A total of $452.6 \mathrm{~km}$ of transects were covered and 103 primate groups were encountered. Details of 


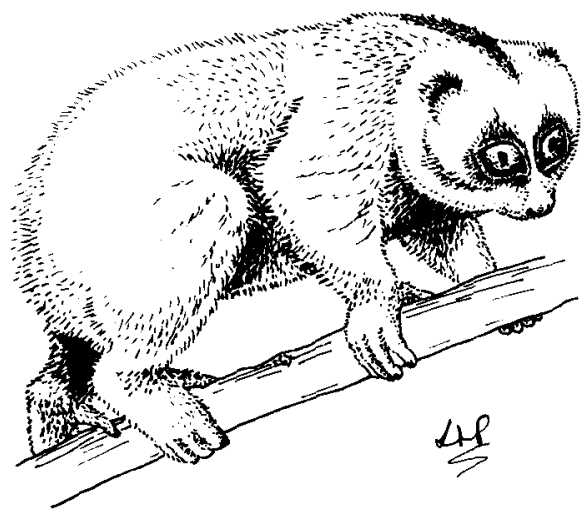

Slow loris

Drawings by Louise Paull

the condition of the various blocks of forest and data for the population estimates can be found in the full report. ${ }^{3}$

Slow loris $N y$ cticebus coucang: not seen; reported as present but rare in several areas of semi-deciduous evergreen forest in Sylhet; not in any forest block in the south-east.

Rhesus macaque Macaca mulatta: an extremely adaptable animal found throughout Bangladesh in all three forest types as well as in close proximity to man in a number of towns and villages. Estimated populations: 126,000 in the Sunderbans; 13,000 in deciduous forest; 3000 in Sylhet; and 134,000 in the south-east, giving an estimated total of 276,000 .

Assamese macaque $M$. assamensis: none seen, but reported by $M d$. Farid Ahsan to be present in Patharia in Sylhet.

Pig-tailed macaque $M$. nemestrina: not previously recorded from Bangladesh; ${ }^{2}$ it appears to be restricted to the deep semi-deciduous/evergreen forest of Sylhet, but its apparent absence in the south-east awaits confirmation from a thorough survey in the Chittagong Hill Tracts. Estimated population only 1200.

Hanuman langur Presbytis entellus: several groups discovered in the villages and fruit gardens around Keshobpur in Jessore $\left(22^{\circ} 55^{\prime} \mathrm{N} ; 89^{\circ} 15^{\prime} \mathrm{E}\right)$, the first substantiated Bangladesh record; previously the Hooghly River was regarded as its eastern boundary. Estimated population about 100 .

Capped langur $P$. pileata: common in both the deciduous forests of Madhupur and North Mymensingh and the semi-deciduous/evergreen forest of Sylhet and the south-east. Estimated population 13,200 in deciduous forest; 3,800 in Sylhet; and 19,600 in the south-east, giving a total of 37,000 . Although reasonably secure now in Bangladesh, it does not have a wide range outside the country, and this population represents one of the best hopes for safeguarding this species from extinction.

Dusky langur $P$. phayrei: restricted to semi-deciduous/evergreen forest and sighted only in Sylhet; absent from the coastal forest of the south-east, but it may be present in the Chittagong Hill Tracts. Estimated population only 1300.

Hoolock gibbon Hylobates hoolock: limited to good quality semi-deciduous/evergreen forest in Sylhet and the south-east, although absent from several forest blocks within this area, possibly because they are drier and more deciduous. The estimated population in Sylhet is 700 and in the south-east 2300, a total of 3000 .

\section{Some Other Species}

During the survey we took the opportunity to question residents in each of the forest blocks about the presence of other species besides the primates. Some interesting data emerged even though identification to species level was not always possible: Table 2. In addition we gathered information on some endangered species, most of it collected and collated by A.W. Akonda from various sources over the last few years:

Wolf Canis lupus: almost certainly extinct in Bangladesh. 
SANGU/

MATAMUHARI

C.H.T.

EASTERN

SITAPAHAR/

RAMPAHAR

C.H.T.

NORTHERN

TEKNAF

PENINSULA

MOHASHKHALI

ISLAND

COX'S BAZAR

NORTHERN

CHOKORIA

SUNDERBANS

CHIT.SOUTH

CHIT.EAST

CHIT.NORTH

PATHARIA

HARARGAJ

RAJKANDI

BHANUGACH

TARAP

RAGHUNANDAN

N.MYMENSINGH

MADHUPUR

BHAWAL

SUNDERBANS
(21) $1-1,1-1=2$

(20)

(19)

(18)

(14)

(10)

(9) $101-1=-1=$

(9) 1210101000100

(7) - $-1 \sin \sin \theta \cos 1$ -

(6) -

(5) $-\infty 1+1 \infty \infty 211-$

(4) $1=1$ | 1 我 $1=1=$

(3) 10111011112

(2)

(1) 10111111012

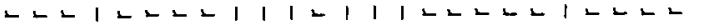

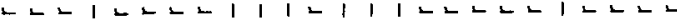




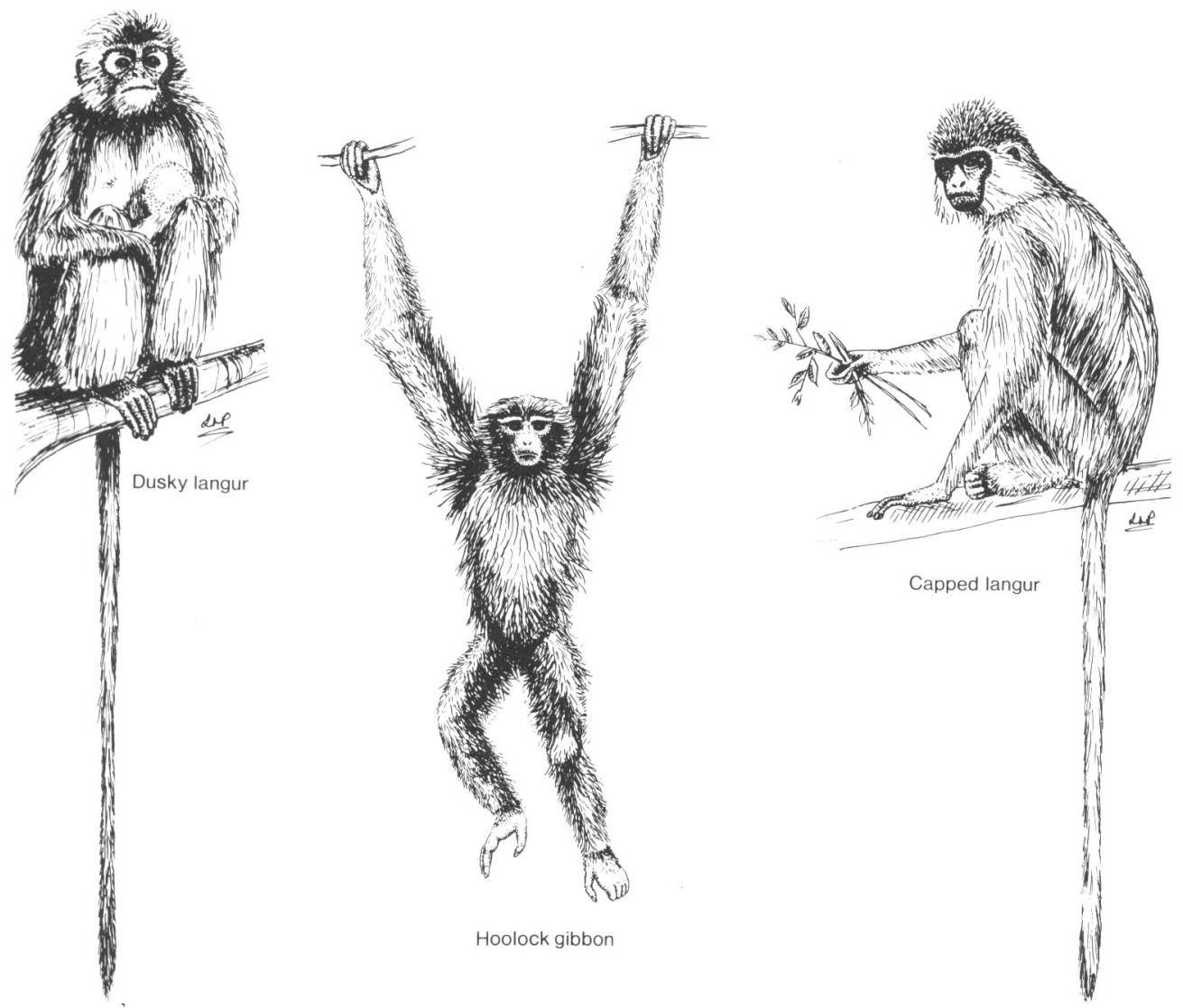

Asiatic Wild Dog Cuon alpinus: still present in the forest of the south-east. Guesstimates of numbers are: Chittagong Northern 50-75: Cox's Bazar Northern 30-50; Teknaf 50-60; Chittagong Hill Tracts Northern 500-600; and Sangu// Matamuhari 400-500. (Note, these estimates appear to be rather optimistic - S.P.G.) Tiger Panthera tigris: quite good numbers in the Sunderbans, estimated at abour 430.450 in 1979; the few reported in North Mymensingh and Partharia probably do not represent stable populations; reported present in the three remaining large areas of forest in the Chittagong Hill Tracts.

Leopard Panthera pardus: apparently absent from the Sunderbans region, aithough formerly reported present in the forest surrounding the mangrove areas. In Sylhet footprints of a large cat were seen at Raikandi, and leopards were also reported present at Patharia; numbers are probably low in both areas. Present in the three remaining large areas of forest in the Chittagong Hill Tracts, but no information on numbers.

Asian Elephant Elephas maximus: numbers reported were Patharia 10-15; Chitragong Eastern one male; Chittagong Southern 5-8; Cox's Bazar Northern 30 40, Teknaf Peninsula 30-40; Chittagong Hill Tracts Northern 96-104; Chittagong Hill Tracts Eastern 50-70; Sangu/Matamuhari 60-70, giving an estimated total of 282-348.

Several mammal species listed as endangered in neighbouring countries which might still occur in Bangladesh include: marbled cat Felis marmorata, Temminck's cat, $F$. temmincki and clouded leopard Neofelis nebulosa. If any do survive in Bangladesh it will be in the Chittagong Hill Tracts or Sylhet.

Bangladesh's endangered birds include white-winged wood duck Cairina scutulata, of which 31 were seen in the Chittagong Hill Tracts Eastern Block in 


\section{Mangrove Forest}

$\begin{array}{ccc}\begin{array}{c}\text { Natural } \\ \text { forest }\end{array} & \begin{array}{c}\text { Scrub } \\ \text { forest }\end{array} & \text { Total } \\ \text { sq km } & \text { sq } \mathrm{km} & \text { sq km }\end{array}$

1. Sunderbans

\begin{tabular}{lrrr}
\multicolumn{1}{c}{ W.S. } & & & \\
a East & 54 & 0 & 54 \\
b South & 177 & 0 & 177 \\
c West & 90 & 0 & 90 \\
& 321 & 0 & 321
\end{tabular}

Deciduous Forest

$\begin{array}{ccc}\begin{array}{c}\text { Natural } \\ \text { forest }\end{array} & \begin{array}{c}\text { Scrub } \\ \text { forest }\end{array} & \text { Total } \\ \text { sq km } & \text { sq km } & \text { sq km }\end{array}$

2. Bhawal

3. Madhupur

N.P.

$\begin{array}{lll}0 & 51 & 51 \\ 21 & 21 & 102 \\ 21 & 72 & 153 \\ & \text { Total } & \\ & & \\ & \text { sq km } & \end{array}$

20

23

$256^{*}$

25

324

$251 \quad 0$
102 153

W.S. = Wildlife Sanctuary, N.P. = National Park.

Semi-Deciduous/Evergreen Forest

(Chittagong Northern)

17. Himchari N.P. (Teknaf Peninsula)

18. Mainimukh W.S.

(Chittagong Hill Tracts

Northern)

19. Rampahar W.S. (Chittagong Hill Tracts)

*An additional $190 \mathrm{sq} \mathrm{km}$ of forest in this reserve is being worked under a clear-felling scheme, so is of little use for wildlife conservation.

1978, and which may occur elsewhere in the Hill Tracts; Normann's or spotted greenshank Tringa guttifer, about which there was no information because of the difficulty in identification; and green peafowl Pavo muticus, which may survive in the Chittagong Hill Tracts.

Endangered reptiles include: river terrapin Batagur baska, about which there was no information; gharial Gavialis gangeticus, probably extinct in Bangladesh; marsh crocodile Crocodylus palustris, and possibly also the estuarine crocodile $C$. porosus, still present in the Sunderbans; and Indian python Python molurus, reported as rare in the north-east Sunderbans, in Patharia and Rajkandi in Sylhet, in Chittagong Northern, Eastern and Southern Blocks, in Cox's Bazar Northern Block and in the Teknaf Peninsula; common in the Chittagong Hill Tracts Northern and Eastern Blocks and in the Sangu/Matamuhari Block.

\section{Evaluation of Wildlife Conservation}

Wildlife conservation requires that endangered species be legally protected and that representative areas of each habitat are set aside as sanctuaries. In Bangladesh most animal species are fully protected from disturbance, hunting, killing and export under the Wildlife (Preservation) Act 1973, although active enforcement is rare because of the lack of trained personnel in the Forest Department. In 1973, Bangladesh signed but has not ratified the Convention on International Trade in Endangered Species of Wild Fauna and Flora (CITES).

The Wildlife Preservation Act also prescribes three types of reserve for the protection of wildlife: wildlife sanctuary, national park and game reserve. A number of forest areas have been designated as protected areas for wildlife at 
different times in the past, and are mentioned in various Forest Department working plans and Wildlife Circle proposals, and described by Olivier. ${ }^{4}$ Of the areas currently regarded as protected in Table 3 only the Sunderbans Wildlife Sanctuary and Himchari National Park have so far been gazetted. The only protected areas with guards are: Mainimukh (4); Rampahar (2); Hazarikhil (1); and the Sunderbans where four boatmen are detailed for wildlife work.

Most of the present reserves were established without prior surveys or preliminary research to assess their effectiveness, and some are totally unsuitable. The emphasis appears to have been to select accessible areas that would appeal to local people, rather than to provide facilities for sightseeing and tourism. Often, normal forestry practices, such as clear-felling, continue in designated reserves, in direct conflict with wildlife requirements. Also, few areas have been clearly defined and officially gazetted by the Government, so have suffered changes in their status and boundaries at the whim of the Forest Department. Thus, there is no comprehensive system of protected areas for wildlife conservation; most exist in name only with no effective protection.

Moreover, the total area of land devoted to reserves in Bangladesh is small compared with may other countries in South-East Asia. ${ }^{1}$ The total land area is $142,771 \mathrm{sq} \mathrm{km}$, of which the remaining natural forest is calculated to be $4782 \mathrm{sq}$ $\mathrm{km}$ ( 3 per cent) and the total of scrub forest $9260 \mathrm{sq} \mathrm{km}$ ( 7 per cent). At present $593 \mathrm{sq} \mathrm{km}$ (12 per cent) of the natural forest and $72 \mathrm{sq} \mathrm{km}$ (one per cent) of scrub forest is regarded as in protected areas. Thus protected natural forest in the country totals only 0.4 per cent of the total land area of Bangladesh.

In the face of great difficulties, the Bangladesh government has made some effort to conserve the country's wildlife and some representative samples of different natural habitats, but it is greatly hampered by the lack of trained personnel at all levels to construct and carry out effective wildlife management plans. Some species, such as rhesus macaque and capped langur, have fairly healthy populations, but most must be regarded as in danger of disappearing because of the continued pressure on the small amount of remaining natural habitat. Biologists and conservation organisations should make all efforts to help in formulating management plans and conservation policy for Bangladesh.

\section{Acknowledgments}

We would like to thank the Bangladesh Forest Department for all their help in this study. Valuable comments on an earlier draft of this paper were given by David Chivers, Jeremy Raemaekers, and Tony Whitten. The project was funded by the Fauna and Flora Preservation Society and the Conder Conservation Trust.

\section{References}

1. CHIVERS, D.J. 1977. The Lesser Apes. In Primate Conservation (Prince Rainier and G.H. Bourne, eds) pp 539-598. Academic Press, London.

2. FOODEN, J. 1975. Taxonomy and evolution of the liontail and pig-tail macaques (Primates: Cercopithecidae). Fieldiana, Zool. 67: 1-169.

3. GITTINS, S.P. 1980. A survey of the Primates of Bangladesh. Project Report to the Forest Department of Bangladesh.

4. OLIVIER, R. 1979. Wildlife conservation in Bangladesh. Report to FAO.

S.P. Gittins, Department of Applied Biology, UWIST, King Edward VII Avenue, Cardiff CF1 3NU. 


\section{Falklands Trust Gets to Work}

The Falkland Islands Trust, set up in the islands early last year, lost no time in getting to work. The first issue of its journal The Warrah (name of the Falkland fox that was exterminated in the early days of settlement) was distributed in September, with articles and records about the wildlife, and an account of the first project it is supporting, the adoption of Hooker's Point by Stanley Senior School. Heavy overgrazing had destroyed much of the tussac grass on the Point, resulting in severe erosion, and the project aims to restore the area. Fences have been repaired and sand grass planted to hold the sand. A plant identification booklet has been put together and the pupils at the school are recording the wildlife. The Falkland Islands Foundation has given $£ 100$ toward the cost of the fencing.

The warrah, the Falkland fox Canis antarcticus, the only endemic mammal in the islands was an inquisitive and confiding animal, larger than European and South American foxes and never very numerous. When the early settlers brought in sheep the foxes were said to have hunted in small groups for fun. By 1876, with the aid of a Government bounty, the farmers had exterminated them.

For a Falkland Islands meeting in London, see page 296.

\section{Another Feral Dog Problem}

The discovery in 1979 that feral goats on Isabela island in the Galapagos had managed to cross the fearsome lava of the Perry Isthmus that divides the island in two, and hitherto considered impassable, has forced the Charles Darwin Research Station to try to eradicate the feral dogs in the south (inhabited) part. The fear is that if goats can cross, so can dogs, which could devastate the wildlife in the uninhabited north - including giant tortoises (five races), flightless cormorants and Galapagos penguins, young fur seals and sea lions, marine and land iguanas and nesting seabirds. If the dogs can be eradicated it will become feasible to return land iguanas to the wild in the south of Isabela; these are being bred at the Station after the population had been almost exterminated by the feral dogs.

\section{Land Iguanas Captive Bred}

The first successful breeding in captivity of land iguanas Conolophus subcristatus from North Seymour island at the Darwin Station in the Galapagos should ensure the perpetuation of the Baltra (South Seymour) race of this iguana. This had become extinct on Baltra and survived only because of a chance translocation of some of them to North Seymour about 50 years ago. However, the North Seymour population was not reproducing well in the wild, because of predation on the young by snakes and frigate birds. Now it is hoped that the young can be reared to a size when they will be safe from predation before being released.

\section{Three Thousand Million Insects a Night}

A 100-metre high cave in Thailand, Tham Ra Kang, home of several million wrinkled-lipped bats Tadarida plicata, is threatened with imminent destruction by limestone quarrying. Local people depend on the bats' guano, which is good fertiliser. One village was able to build a school $(\$ 100,000)$ with money raised from the sale of the guano, and another built a temple at twice that cost. Moreover, these bats are estimated to eat 3000 insects each per night, so that the smailest colony may consume 3000 million every night, many of them crop pests. 